\title{
Relationship between disease severity and inflammatory markers in cystic fibrosis
}

Division of Allergy and Pulmonology, University Children's Hospital, Vienna, Austria

D Y Koller

C Wojnarowski

I Eichler

\section{Department of} Paediatric Infectious Diseases, Wilhelminen Hospital, Vienna, Austria

M Götz

Correspondence to: Dr Dieter Koller, University Children's Hospital, Währinger Gürtel 18-20, 1090 Vienna, Austria.

Accepted 2 July 1996

\author{
Dieter Y Koller, Manfred Götz, Claudia Wojnarowski, Irmgard Eichler
}

\begin{abstract}
To evaluate the clinical use of measuring neutrophil, lymphocyte, and eosinophil activities, serum myeloperoxidase (MPO), soluble interleukin-2 receptors (sIL-2R), and eosinophil cationic protein (ECP) were measured in 98 patients with cystic fibrosis and in 85 healthy children. Serum concentrations of MPO, sIL-2R, and ECP were increased in patients with cystic fibrosis (median $807 \mu \mathrm{g} / 1,4452$ $\mathrm{pg} / \mathrm{ml}, 48.8 \mu \mathrm{g} / \mathrm{l}$, respectively) compared with the controls (median $319 \mu \mathrm{g} / 1,2743$ $\mathrm{pg} / \mathrm{ml}, 9.4 \mu \mathrm{g} / \mathrm{l})$. ECP concentrations, but not serum MPO or sIL-2R, were significantly related to disease severity assessed by the Shwachman-Kulczycki score and by pulmonary function (forced expiratory volume in one second \% predicted). Neither ECP nor sIL-2R was influenced by Pseudomonas aeruginosa infection, acute pulmonary exacerbation, or atopy. Serum MPO, however, was strongly correlated with acute pulmonary exacerbation. In the light of these findings the measurement of serum ECP might thus be used for clinical monitoring and for assessing disease severity in cystic fibrosis. The measurement of serum MPO and sIL-2R did not correlate with the disease severity.

(Arch Dis Child 1996;75:498-501)
\end{abstract}

Keywords: cystic fibrosis, eosinophil cationic protein myeloperoxidase, soluble interleukin 2 receptor.

The most frequent clinical manifestation in patients with cystic fibrosis is progressive pulmonary destruction due to chronic endobronchial infection. There is increasing evidence that immune mediated inflammation also contributes to progressive pulmonary tissue damage. Knowledge about the immune processes in cystic fibrosis allows us to analyse and quantitate cells or cell products suggested to be involved in the pathology and to follow changes as a reflection of pulmonary disease in cystic fibrosis. ${ }^{1-4}$ Eosinophils appeared to play a minor part until the demonstration of highly activated eosinophils measured by eosinophil cationic protein (ECP) concentrations in patients with cystic fibrosis. ${ }^{12}$ In addition, assessment of pulmonary inflammation is possible by measuring cell products in blood samples. ${ }^{125}$ Persistence of endobronchial infection may cause an excessive immune response, ${ }^{6}$ reflected by high concentrations of immunoglobulins, immune complexes, and neutrophil products - for example, elastase and myeloperoxidase (MPO). ${ }^{7}$ Concentrations of soluble interleukin-2 receptors (sIL-2R), a marker of $\mathrm{T}$ lymphocyte activation, have been shown to be increased even before any clinical evidence of lung inflammation due to infection in cystic fibrosis. ${ }^{3}$ Thus pulmonary manifestations in cystic fibrosis may be considered as an inflammatory disease.

In this study, the activation of neutrophils, lymphocytes, and eosinophils was examined by measuring concentrations of MPO, sIL-2R, and ECP in serum samples from healthy subjects and from patients with cystic fibrosis of variable disease severity to determine their role in the assessment of the clinical disorder.

\section{Patients and methods}

PATIENTS AND CONTROLS

Ninety eight patients with cystic fibrosis from the Cystic Fibrosis Care Center Vienna were studied (mean (SD) age 11.0 (7.69) years; 45 boys and 53 girls). Fifty four patients were infected with Pseudomonas aeruginosa, 68 with Staphylococcus aureus, and 46 with Haemophilus influenzae, as determined by sputum cultures. The diagnosis of acute pulmonary exacerbation in 39 patients with cystic fibrosis was defined as a marked increase of $\mathrm{C}$ reactive protein (median $86 \mathrm{mg} / \mathrm{l}$ ), by weight loss, anorexia, increased cough, increased sputum production, fever with and without new lung infiltrates, and deterioration of oxygen saturation and pulmonary function. Atopy was present in 31 patients and of these 22 were sensitised against Aspergillus fumigatus. A patient was considered atopic if total serum IgE antibody levels (median total serum IgE $456 v 22 \mathrm{kU} / \mathrm{l}$; $\mathrm{p}<0.0001$ ) were increased (above the age dependent normal values) and if specific IgE antibodies ( $\geqslant$ class 2 ) against more than one allergen could be detected. None of the patients had received steroids within a month before drawing blood.

Eighty five healthy non-atopic subjects (10.8 (5.68) years) with normal total IgE concentrations (median serum IgE $24 \mathrm{kU} / \mathrm{l}$ ) were recruited as controls. Blood was obtained at routine sampling for clinical evaluation.

\section{ASSESSMENT OF DISEASE SEVERITY AND}

PULMONARY FUNCTION

Disease severity was assessed by the Shwachman-Kulczycki score, ${ }^{8}$ which in our setting was limited to a maximum of 75 (excluding radiography). The following pulmonary function tests were performed in 67 patients with cystic fibrosis: forced vital capac- 
Table 1 Influence of acute pulmonary exacerbation and $P$ aeruginosa infection on serum levels of ECP, MPO, and sIL-2R in 98 patients with cystic fibrosis

\begin{tabular}{|c|c|c|c|c|c|c|}
\hline & \multicolumn{3}{|c|}{ Acute pulmonary exacerbation } & \multicolumn{3}{|c|}{$P$ aeruginosa infection } \\
\hline & With $(n=39)$ & $\begin{array}{l}\text { Without } \\
(n=59)\end{array}$ & p Value & With $(n=54)$ & $\begin{array}{l}\text { Without } \\
(n=44)\end{array}$ & p Value \\
\hline $\mathrm{ECP}(\mu \mathrm{g} / \mathrm{l})$ & $\begin{array}{l}61.6 \\
(23.4-75.8)\end{array}$ & $\begin{array}{l}44.9 \\
(14.8-65.0)\end{array}$ & NS & $\begin{array}{l}48.0 \\
(28.5-76.6)\end{array}$ & $\begin{array}{l}49.8 \\
(13.8-66.9)\end{array}$ & NS \\
\hline MPO $(\mu \mathrm{g} / \mathrm{l})$ & $\begin{array}{l}1342 \\
(1003-1769)\end{array}$ & $\begin{array}{l}626 \\
(495-804)\end{array}$ & $\begin{array}{l}< \\
0.0001\end{array}$ & $\begin{array}{l}1007 \\
(588-1780)\end{array}$ & $\begin{array}{l}698 \\
(495-798)\end{array}$ & $\begin{array}{l}< \\
0.001\end{array}$ \\
\hline $\begin{array}{l}\text { sIL-2R } \\
\quad(\mathrm{pg} / \mathrm{ml})\end{array}$ & $\begin{array}{l}5040 \\
(4116-7014)\end{array}$ & $\begin{array}{l}4410 \\
(3570-6804)\end{array}$ & NS & $\begin{array}{l}4452 \\
(3780-6840)\end{array}$ & $\begin{array}{l}4536 \\
(3528-6762)\end{array}$ & NS \\
\hline
\end{tabular}

Results are presented as median (quartile 1 - quartile 3); $p$ values indicate significant differences between the groups (Mann-Whitney U test). NS = not significant.

Table 2 Correlation (r) of ECP, MPO, and sIL-2R and various clinical parameters

\begin{tabular}{llll}
\hline & ECP & $M P O$ & sIL-2R \\
\hline Shwachman score & $-0.613 ; \mathrm{p}<0.0001$ & $-0.197 ; \mathrm{p}<0.005$ & $0.080 ; \mathrm{NS}$ \\
Forced vital capacity & $-0.493 ; \mathrm{p}<0.0001$ & $-0.227 ; \mathrm{p}<0.01$ & $0.048 ; \mathrm{NS}$ \\
FEV $_{1}(\%)$ & $-0.532 ; \mathrm{p}<0.0001$ & $-0.195 ; \mathrm{p}<0.05$ & $0.102 ; \mathrm{NS}$ \\
$\mathrm{MEF}_{50}(\%)$ & $-0.475 ; \mathrm{p}<0.0001$ & $-0.227 ; \mathrm{p}<0.01$ & $0.083 ; \mathrm{NS}$ \\
IgE & $0.121 ; \mathrm{NS}$ & $0.099 ; \mathrm{NS}$ & $0.009 ; \mathrm{NS}$ \\
\hline
\end{tabular}

Correlation was calculated by means of the Kendall Tau B test. NS = not significant.

ity, forced expiratory volume in one second $\left(\mathrm{FEV}_{1}\right)$, and maximum expiratory flow at $50 \%$ of vital capacity $\left(\mathrm{MEF}_{50}\right)$. These were recorded in the form of a maximum flow volume curve (Masterlab, Jaeger, Germany) according to the American Thoracic Society standard. ${ }^{9}$ Results were presented as a percentage predicted based on accepted reference standards. ${ }^{10}$

\section{BLOOD SAMPLES}

The cell numbers were counted using an automated haematology analyser (Sysmex NE5500, Müller GesmbH, Austria) with coefficients of variation for eosinophils less than $7 \%$. $^{1}$ The ECP/MPO ratios were determined using specific and sensitive radioimmunoassays (Pharmacia, Sweden) in duplicate. ${ }^{11}{ }^{12}$ In brief, ECP/MPO ratios in serum samples compete with a fixed amount of ECP/MPO labelled with ${ }^{125} \mathrm{I}$ for the binding sites of specific antibodies. sIL-2R levels were assessed by immunoenzymometric assays (Immunotech, France) in which monoclonal antibodies directed against two different epitopes of sIL-2R were used. ${ }^{4}$ All methods showed interassay coefficients of variation lower than $10 \%$.

\section{STATISTICAL ANALYSIS}

Results are expressed as median (quartile 1 quartile 3) unless stated otherwise. Nonparametrical statistical tests were used in the comparative analysis. Each pairing was examined using the Mann-Whitney U test. Correlation coefficients $(r)$ were obtained by using the Kendall Tau B method. The level of significance was considered at $\mathrm{p}<0.05$.

\section{Results}

CHARACTERISTICS OF PATIENTS

Three patients with cystic fibrosis had severe disease according to the Shwachman scoring system, 17 had moderate, and 41 had mild disease. Twenty nine patients had a good and eight a very good clinical status. The forced vital capacity was $60.4 \%(46.2-88.2 \%)$ predicted, the $\mathrm{FEV}_{1}$ was $69.8 \%(54.8-81.1 \%)$ predicted, and the $\mathrm{MEF}_{50}$ was $41.0 \%$ (13.0$70.4 \%)$.

EOSINOPHIL COUNTS AND SERUM ECP

Eosinophil counts did not differ between patients with cystic fibrosis (220 (160-301) cells $/ \mu \mathrm{l})$ and the control subjects (245 (143368) cells $/ \mu \mathrm{l})$, whereas serum ECP concentrations were increased $(48.8(16.5-68.2) v 9.4$ $(6.6-12.0) \mu \mathrm{g} / \mathrm{l} ; \mathrm{p}<0.0001)$. Eosinophil counts and ECP levels from atopic patients with cystic fibrosis (median 229 cells $/ \mu \mathrm{l}$ and $54.6 \mu \mathrm{g} / \mathrm{l}$, respectively) were also not different from those of the non-atopic patients (median $220 \mathrm{cells} / \mu \mathrm{l}$ and $44.9 \mu \mathrm{g} / \mathrm{l}$, respectively). In addition, eosinophil counts and serum ECP concentrationss (table 1 ) were not influenced by $P$ aeruginosa infection (median eosinophil counts of infected subjects 208 cells $/ \mu l v$ non-infected patients $226 \mathrm{cell} / \mu \mathrm{l})$ and acute pulmonary exacerbation (median eosinophil counts $198 v$ 220 cells $/ \mu \mathrm{l}$ ). Division of the data into classes among the Shwachman score indicated a relation of serum ECP measurements to disease severity (fig 1, table 2). Moreover, serum ECP concentrations were significantly correlated with pulmonary function (table 2, fig 2).

NEUTROPHIL COUNTS AND SERUM MPO

Neutrophil counts in patients with cystic fibrosis $(5510(3450-7540)$ cells $/ \mu \mathrm{l})$ were increased compared with healthy controls (4501 (3245$6001)$ cells $/ \mu \mathrm{l} ; \mathrm{p}<0.01$ ). Serum MPO concentrations were also increased in the patients compared with the controls $(807$ (546-1235) $v$ $319(211-401) \mu \mathrm{g} / \mathrm{l} ; \mathrm{p}<0.0001)$. In patients with $P$ aeruginos $a$ infection or acute pulmonary exacerbation MPO concentrations were significantly higher than in non-infected patients (table 1). Not surprisingly, atopy did not influence neutrophil activities (median MPO concentrations $873 v 818 \mu \mathrm{g} / 1$ ). Moderate correlations were seen between MPO concentrations and disease severity (fig 1 , table 2 ).

LYMPHOCYTE COUNTS AND SERUM SIL-2R

No difference was seen between lymphocyte counts in patients with cystic fibrosis and in controls (median $2520 v 2490$ cells/ $\mu \mathrm{l}$ ). However, sIL-2R concentrations were increased in the patients $(4452(3780-6804) \quad v \quad 2743$ (2016-3318) $\mathrm{pg} / \mathrm{ml} ; \mathrm{p}<0.0001$ ) (fig 1). In contrast with the measurements of ECP and MPO, sIL-2R concentrations were significantly higher in children less than 4 years of age compared with the patients after 4 years of age (3696 (3276-4158) v 2464 (2016-2716) $\mathrm{pg} / \mathrm{ml} ; \mathrm{p}<0.001)$. Neither atopy, $P$ aeruginosa infection, acute pulmonary exacerbation, nor the clinical status influenced sIL-2R concentrations (tables 1 and 2).

\section{Discussion}

Activated neutrophils and eosinophils have been demonstrated to have a deleterious effect on pulmonary tissue in cystic fibrosis. ${ }^{713} \mathrm{Neu}-$ trophil and eosinophil products together with chronic bacterial infection lead to progressive pulmonary destruction, finally resulting in respiratory failure and death. The role of the neu- 

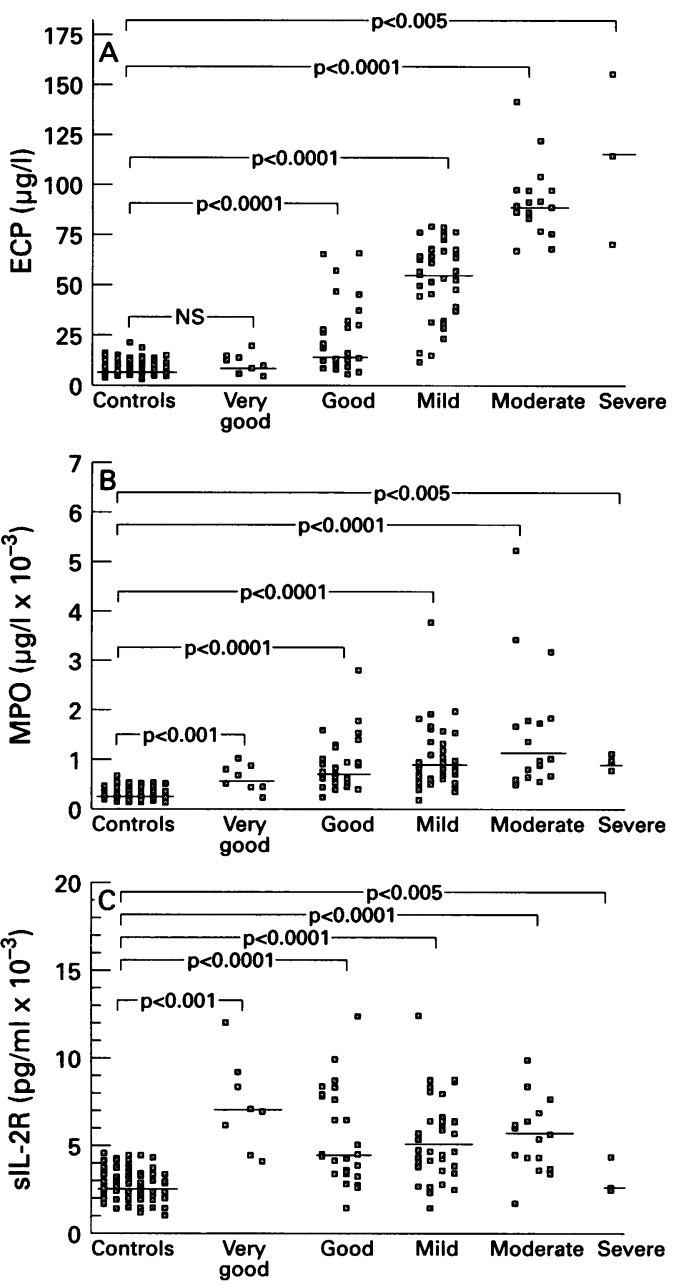

Figure 1 Serum concentrations of (A) ECP in $\mu g / l,(B)$ $M P O$ in $\mu g / l$, and $(C) s I L-2 R$ in $\mathrm{pg} / \mathrm{ml}$ in patients with cystic fibrosis related to the Shwachman-Kulczycki scoring system compared with healthy controls. Median ECP concentrations in patients with cystic fibrosis subdivided into different groups among the Shwachman-Kulczycki scoring system: 1 , very good, $11.2 \mu \mathrm{g} / \mathrm{l} ; 2$, good, $16.4 \mu \mathrm{g} / \mathrm{l} ; 3$, mild, 56. $3 \mu \mathrm{g} / \mathrm{l} ; 4$, moderate, $89.2 \mu \mathrm{g} / \mathrm{l} ; 5$, severe, $115 \mu \mathrm{g} / \mathrm{l}$. Median MPO concentrations, 1 , very good, $600 \mu \mathrm{g} / \mathrm{l} ; 2$, good, $697 \mu \mathrm{g} / l ; 3$, mild, $804 \mu \mathrm{g} / \mathrm{l} ; 4$, moderate, $1003 \mu \mathrm{g} / \mathrm{l}$; and (5) severe, $951 \mu \mathrm{g} / \mathrm{l}$. Median sIL-2R levels: 1 , very good, $6972 \mathrm{pg} / \mathrm{ml} ; 2$, good, $4410 \mathrm{pg} / \mathrm{ml} ; 3$, mild, $4620 \mathrm{pg} / \mathrm{ml}$ 4 , moderate, $5376 \mathrm{pg} / \mathrm{ml}$; and 5 , severe, $2562 \mathrm{pg} / \mathrm{ml}$. Statistical differences were calculated by using the Mann-Whitney U test. NS, not significant.

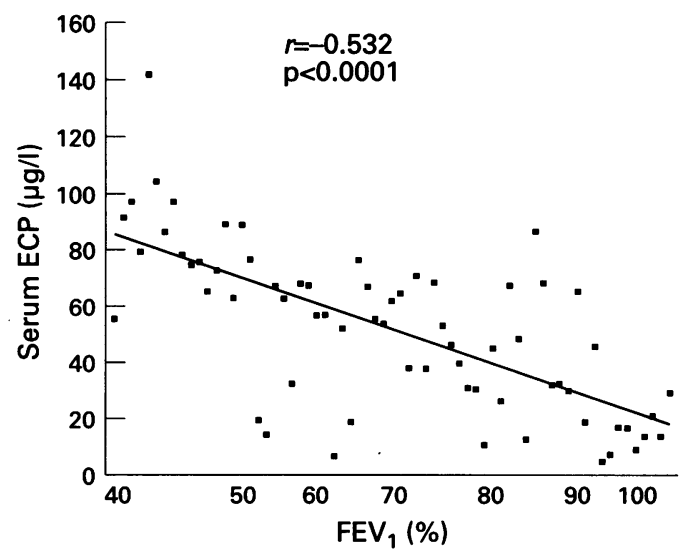

Figure 2 Correlation between serum ECP concentrationss and $F E V, \%$ predicted in patients with cystic fibrosis. Correlation was calculated by means of the Kendall Tau B Corr. trophil and its products in cystic fibrosis were elucidated several years ago. ${ }^{7}$ These results show a strong relationship between neutrophil activation - that is, MPO concentrations-and pseudomonas infection or acute pulmonary exacerbation. As acute pulmonary exacerbation is generally accepted to be an indication of intravenous antibiotic treatment in cystic fibrosis, the assessment of MPO in peripheral blood may be used as an indicator to start antimicrobial treatment and to monitor the efficacy of the treatment. ${ }^{1}$ We have previously shown that antimicrobial treatment reduces serum MPO concentrations which, however, do not return to normal values in patients with cystic fibrosis. ${ }^{1}$ This observation thus allows us to hypothesise that, in addition to antibiotic treatment, anti-inflammatory treatment may be indicated in cystic fibrosis.

Raised sIL-2R serum concentrations also indicate anti-inflammatory efforts. In contrast with MPO or ECP concentrations, we did not observe a relationship between sIL-2R and clinical variables. It appears that sIL-2R concentrations show lymphocyte activation and thus explain the excessive immune response in cystic fibrosis. ${ }^{6}$ It has been speculated that lymphocyte activity may be an early indicator of a developing inflammatory process in cystic fibrosis and the first sign of airway infection ${ }^{3}$; however, the role of increased sIL-2R concentrations remains to be further investigated.

The role of the activated eosinophil and its products in cystic fibrosis has been investigated previously. ${ }^{12}$ The eosinophil is increasingly thought to be a proinflammatory cell in chronic inflammatory respiratory disorders with tissue damaging capacities. ${ }^{5}{ }^{13}$ In cystic fibrosis other mechanisms of eosinophil activation than in bronchial asthma should be considered, as in cystic fibrosis eosinophil numbers are within the normal range. ${ }^{1}$ We have shown that eosinophils of patients with cystic fibrosis have an increased propensity to release their granule proteins, ${ }^{2}$ which may explain the high ECP concentrations in sputum and serum. ${ }^{1}$ Eosinophil activity expressed as ECP concentrations was more related to clinical variables such as pulmonary function and the ShwachmanKulczycki score than were markers of neutrophils and lymphocytes. It has also been shown that mucociliary clearance is decreased in patients with cystic fibrosis who have a normal lung function. ${ }^{14}$ It has been suggested that eosinophil products might be responsible for this phenomenon..$^{15}$ We were previously able to show that antipseudomonal treatment did not reduce ECP concentrations. ${ }^{1}$ These data support the therapeutic recommendation of the use of anti-inflammatory drugs in cystic fibrosis. ${ }^{16} 17$

In conclusion, the exaggerated inflammatory process in the lungs of patients with cystic fibrosis could be measured in peripheral blood. The assessment of neutrophil activity, measured as MPO concentrations, may be useful in documenting acute pulmonary exacerbations and the infectious status of the patient and to monitor the efficacy of antimicrobial treat- 
ment. Concentrations of ECP, a specific marker of eosinophil activation, are strongly related to disease severity in patients with cystic fibrosis and may thus be useful for clinical monitoring in the disease.

1 Koller DY, Götz M, Eichler I, Urbanek R. Eosinophilic activation in cystic fibrosis. Thorax 1994;49:496-9.

2 Koller DY, Urbanek R, Götz M. Increased degranulation of eosinophil and neutrophil granulocytes in cystic fibrosis. Am $\mathcal{F}$ Respir Crit Care Med 1995;152:629-33.

3 Dagli E, Warner JA, Besley CR, Warner JO. Raised serum soluble interleukin-2 receptor concentrations in cystic fibrosis patients with and without evidence of lung disease. Arch Dis Child 1992;67:479-81.

4 Koller DY, Götz M. Clinical relevance of raised soluble serum interleukin-2 receptor concentrations in cystic fibrosis. Arch Dis Child 1993;68:150.

5 Venge P, Dahl R, Fredens K, Hällgren R, Peterson C. Eosinophil cationic proteins (ECP and EPX) in health and disease. In: Yoshida T, Torisu M, eds. Immunobiology of the ease. In: Yoshida T, Torisu M, eds. Immun

6 Hoiby N, Schiotz PO. Immune complex mediated tissue damage in the lungs of cystic fibrosis patients with chronic Pseudomonas aeruginosa infection. Acta Paediatr Scand 1982:301 (suppl):63-73.

7 Mohammed JR, Mohammed BS, Pawluk LJ, Bucci DM Baker NR, Davies WB. Purification and cytotoxic potentia of myeloperoxidase in cystic fibrosis sputum. $\mathcal{F} \mathrm{Lab} \mathrm{Clin}$ Med 1988;122:711-20.
8 Shwachman H, Kulzcycki L. Long-term study of 105 patients with cystic fibrosis. Am 7 Dis Child 1958;96:6-15. American Thoracic Society. Standardization of spirometry-1987 update. Am Rev Respir Dis 1987;136: spirometry

10 Zapletal A, Samanek M, Paul T. Lung-function in children and adolescents. Methods, reference values. Prog Respir Res 1987;22:113-218.

11 Peterson CGB, Enander I, Nystrand J, Anderson AS, Nilsson L, Venge P. Radioimmunoassay of human eosinophil cationic protein (ECP) by an improved method. Establishment of normal levels in serum and turnover in vivo. Clin ment of normal levels in se

12 Olofsson T, Olsson I, Venge P, Elgefors B. Serum myeloperoxidase and lactoferrin in neutropenia. Scand $\mathcal{f}$ Haematol 1977;18:73-88.

13 Flavahan NA, Shifman NR, Gleich GJ, Vanhutte PM. Human eosinophil major basic protein causes hyperreactivity of respiratory smooth muscle: role of the epithelium. $\mathrm{Am}$ ity of respiratory smooth muscle:

14 Regnis JA, Robinson M, Bailey DL, et al. Mucociliary clearance in patients with cystic fibrosis and in normal subjects. Am $\mathcal{F}$ Respir Crit Care Med 1994;150:66-71.

15 Petty TL. Cystic fibrosis. In: Bone RC, Petty TL eds. Yearbook of pulmonary disease. Chicago: Mosby, 1995:6.

16 Eigen H, Rosenstein BJ, FitzSimmons S, et al. A multicenter study of alternate-day prednisone therapy in patients with cystic fibrosis. $\mathcal{F}$ Pediatr 1995;126:515-23.

17 Konstan MW, Byard PJ, Hoppel CL, Davis PB. Effect of high-dose ibuprofen in patients with cystic fibrosis. $N$ Engl f Med 1995;332:848-54. 